\title{
TAXONOMIC AND PHYSIOECOLOGICAL SIGNIFICANCE OF THE FLORAL- SURFACE MICROMORPHOLOGY OF VANDA HELVOLA AND VANDA DEAREI (ORCHIDACEAE)
}

\author{
EDWARD ENTALAI BESI, LING SWEE CHIE AND RUSEA GO* \\ Department of Biology, Faculty of Science, Universiti Putra Malaysia, 43400 Serdang, Selangor Darul Ehsan, Malaysia.
}

*Corresponding author: rusea@upm.edu.my

Submitted final draft: 14 August $2021 \quad$ Accepted: 23 September $2020 \quad$ http://doi.org/10.46754/jssm.2021.07.002

\begin{abstract}
The Vanda orchid is appreciated for its large, beautiful, scented flowers. Anatomical enumeration of the most compatible Vanda species holds interesting and under-investigated aspects. We conducted an in-depth investigation into the floral-surface micromorphology of $V$. helvola and $V$. dearei, and assessed the significance in taxonomic delimitation using scanning electron microscopy (SEM) to feasibly answer questions on the reported dubious origins of certain Vanda species and hybrids. Floral trichomes, including papillae structures, stomata, epicuticular ornamentation and waxes, were enumerated and compared between the selected species. Findings based on the photomicrographs revealed that $V$. helvola and $V$. dearei were comparable based on the diversity and dissemination of trichomes, stomata and epicuticular ornamentation. Noteworthy was the heterogeneous occurrence of distinguishing barrel-shaped glandular trichomes with aperture, which might also function as nectaries, and branched glandular and biseriate trichomes on the labellum of $V$. helvola, but was absent in $V$. dearei. In contrast, an aggregation of conical papillae occurred on the spur of $V$. dearei, but lacking in $V$. helvola. We also employed SEM observations to understand the role of surface microstructures in physio-ecological functions. The glandular trichomes and stomata were presumed to be secretory structures for the unique scents of $V$. helvola and $V$. dearei.
\end{abstract}

Keywords: Ecological demands, epicuticular, floral anatomy, Malaysia, species delimitation, vandaceaous orchids.

\section{Introduction}

The genus Vanda R.Br. of the Orchidaceae family comprises 73 species that may be found from the Himalayas to South China, across Sri Lanka to Southeast Asia, and Papua New Guinea to Northern Australia (Gardiner \& Cribb, 2013; Govaerts et al., 2020). Many species are considered endemic in southeast Asian archipelagos (Gardiner et al., 2013). The generic name "Vanda" originates from Sanskrit, and was proposed by Williams Jones in 1975, which was then used to describe the type species Vanda tessellata (Roxb.) Hook. ex G.Don (Hodgson et al., 1991). Vandas are previously divided into two groups appertaining to their vegetative structures - the strapleaved $V$. tricolor Lindl. and the terete-leaved $V$. teres (Roxb.) Lindl. [= Papilionanthe teres (Roxb.) Schltr.] and $V$. hookeriana Rchb.f. [= Papilionanthe hookeriana (Rchb.f.) Schltr.] (Lim et al., 1999).
Morphologically, the $V$. tricolor group has strap-like leaves, besides being distichous, stem-clasping, keeled, green above and light beneath with the apex erose. Meanwhile, the $V$. teres group differs by having terete leaves as thick as a standard pencil, with the basal parts surrounding the stem (Hodgson et al., 1991). The former group has been declassified from Vanda and placed into a separate genus, the Papilionanthe Schltr. The inflorescence of Vanda orchids is characterised as erect and unbranched, culminating in few to many colourful large flowers, but mostly yellow-brown with markings to attract carpenter bees (Teoh, 1980). All species have a stout column, saccate spur and three-lobed labellum (Pridgeon, 1999). Sepals and petals are usually equal in size and round.

However, classification of Vanda has been described as a "taxonomic black hole" requiring "a complete revision" (Christenson, 1987; Gardiner, 2012). Vanda species exhibit 
remarkably low genetic divergence, in spite of the vivid morphological variations seen across the genus and its broad geographical range. For instance, $V$. helvola occurs in Borneo and Peninsular Malaysia, whereas $V$. dearei from the same section, sect. Deltaglossa, occurs exclusively in Borneo (Gardiner et al., 2013). In Malaysia, $V$. helvola and $V$. dearei are the most utilised species for hybridisation and closely related with almost similar vegetative structures. $V$. helvola is the most widespread species in the genus, which is commonly found in the montane and riverine forests of Malaysia. A special feature of this species is its large flat, triangular deltoid and yellow labellum (Seidenfaden \& Wood, 1992). V. dearei is a strap-leaved orchid which can be found at lowlands, hills and riverine forests. It is special for its large, strongly fragrant and pure yellow flowers devoid of spots that bloom frequently (Chan et al., 1994). These morphological characters make ranks it among the most preferred and ecstatic orchid species, and extensively used as a progenitor of many merited hybrids (Loh et al., 1978). However, the species itself is rare and threatened in the wild due to over collection.

Profiling work to detail the plant's morphology, phylogeny, floral microstructure and cytology in distribution population size, and micropropagation of the Vanda species are now deemed useful. With a genus as horticulturally important as Vanda, the potential for natural hybridisation and introgression between cultivated specimens is high, especially if the morphological differences between species are not well understood (Gardiner et al., 2013). The floral-surface microstructure of the flower part can provide valuable taxonomic and systematic evidence to discriminate between orchids with dubious genetic origins. This study represents the first comprehensive survey of floral-surface micromorphological characteristics of $V$. helvola and $V$. dearei via scanning electron microscopy (SEM) observations to assist in an identification of the mother parents of their hybrids, and to understand its physio-ecological significance in relation to scent production and pollination mechanism.

\section{Materials and Methods}

Samples of florets for each species were collected from living plants during a convenience sampling and assigned a voucher number as stated in Table 1. Collected specimens were processed according to the technique outlined in Bridson \& Forman (2000) and deposited in the Herbarium of Universiti Putra Malaysia (UPM) in Serdang, Selangor. The flowers (Figure 1) were dissected and identified based on the illustrations and descriptions of Seidenfaden \& Wood (1992) and Chan et al. (1994). Accepted names and current distribution were validated through the KEW World Checklist of Selected Plant Families (WCSP) (Govaerts et al., 2020).

Floral-surface micromorphology examination was conducted using SEM in the Anatomy Lab and Scanning Electroscope Room in the Faculty of Agriculture, UPM. The Copenhagen-preserved flower parts were cut into a number of $1 \mathrm{~cm}$ slices, put into separate vials and fixed in formalin acetic acid. Excised segments were then post-fixed in $1 \%$ osmium tetroxide overnight. Afterwards, the experiment was continued with the dehydration process. Samples were passed through ethanol in a series of concentrations; 50 $\%, 75 \%, 90 \% 95 \%$, and $100 \%$, each for 30 minutes, and the final step was repeated in 100 $\%$ ethanol for another 30 minutes. The samples were then transferred into specimen baskets and subjected to critical point drying using a liquid $\mathrm{CO}_{2}$ critical dryer for about 70 minutes.

Table 1: Vanda species examined including their locality, habitat and voucher

\begin{tabular}{lllll}
\hline \multicolumn{1}{c}{ Species } & Type Locality & Habitat & Voucher Deposited & Collector's name \\
\hline V. helvola & Pahang & Hill forest & SC001 & Rusea Go \\
V. dearei & Sabah & Hill forest & SC002 & Rusea Go \\
\hline
\end{tabular}




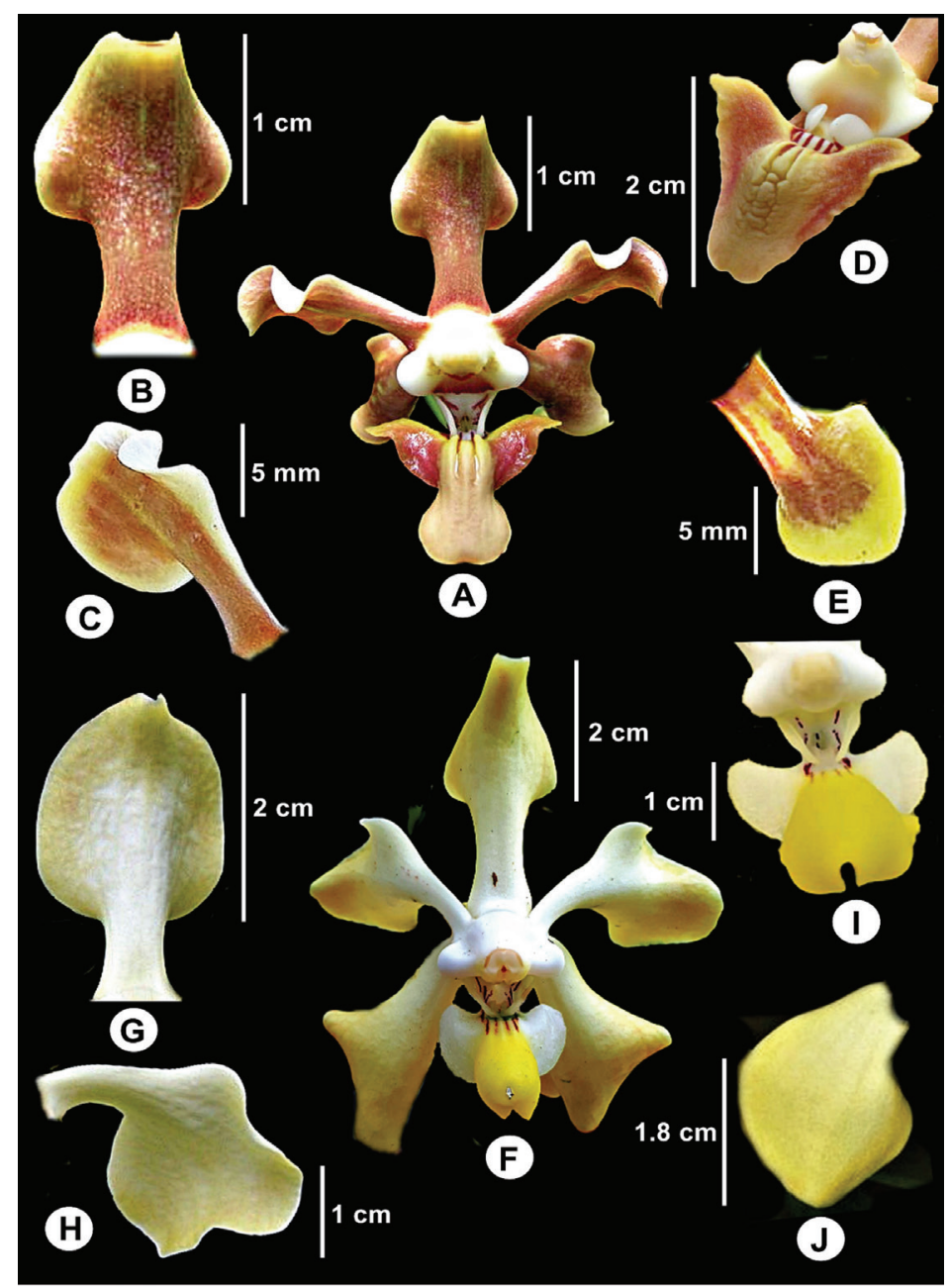

Figure 1: Vanda helvola (A-E); A: Flower, B: Dorsal sepal, C: Petal, D: Labellum and column, E: Lateral sepal. Vanda dearei (F-J); F: Flower, G: Dorsal sepal, H: Petal, I: Labellum, J: Lateral sepal

Dried samples were mounted onto the stub by means of double-sided carbon adhesive tabs and were gold-coated in sputter coater. Samples viewing were done under a JEOL-JSM 5610 LV scanning electron microscope (Jeol Ltd, Tokyo, Japan). The floral-surface microstructures of the anther, column, dorsal sepal, lateral sepals, petals, labellum, pollinium and spur were observed at various magnifications. The microstructures observed were trichomes, including papillary structures, stomata, epicuticular ornamentation and waxes. Stomatal architecture was described by referring to an illustration and terminologies of basal angiosperms stomata in Carpenter (2005) based on the number, form and arrangement of specialised epidermal cells associated with stomatal cells. Comprehensive terminologies of trichome morphology were described according to Adedeji et al. (2007) and Angulo \& Dematteis (2014). Enumeration of trichomes required four steps: (1) examination of the overall surface appearance (indumentum); (2) investigation of the morphology of individual trichomes; (3) study of the trichome complement; and, (4) histological description of trichomes (glandular or non-glandular, unicellular or multicellular, uniseriate or biseriate) based on the clear partitioning of cells on the well-developed 
trichomes.

Parameter measurements were done using a ruler under a clear magnification, and the values obtained were multiplied with the magnification scales. For the individual stomatal parameters, measurement methods in Savvides et al. (2011) and Shope \& Mott (2006) were employed in the current study. Epicuticular ornamentation was described following Piwowarczyk (2015), Ghimire et al. (2018) and Kong \& Hong (2018), and description of epicuticular waxes was based on Wilkinson (1979). The micromorphological features were comparatively described following outline in Ghazalli et al. (2019).

Table 2: Type and morphology of simple, branched, uniseriate and multiseriate trichomes on the floral parts of $V$. helvola and $V$. dearei

\begin{tabular}{ll}
\hline \multicolumn{1}{c}{ Type } & \multicolumn{1}{c}{ Morphology description } \\
\hline I & glandular, multicellular stalk, unicellular head, short $(<30 \mu \mathrm{m})$, capitate \\
II & glandular, short $(<300 \mu \mathrm{m})$, barrel-shaped glandular trichomes with aperture \\
III & glandular, biseriate, multicellular head, long $(300-1000 \mu \mathrm{m})$, pedunculate \\
IV & glandular, biseriate, multicellular head, short $(<300 \mu \mathrm{m})$, club-shaped \\
V & glandular, biseriate, branched, Y-shaped, long $(300-1000 \mu \mathrm{m})$ \\
VI & glandular trichomes with single secretory cell at the tip, short $(>300 \mu \mathrm{m})$, multicellular stalk, \\
& unicellular head \\
VII & non-glandular, unicellular, short $(<300 \mu \mathrm{m})$, flattened, strap-shaped \\
Papillae & globular or tall, striated \\
\hline
\end{tabular}

Table 3: Type and morphology of epicuticular ornamentation on the floral parts of $V$. helvola and $V$. dearei

\section{Results}

Floral parts could be homogenous that consisted of the same type of microstructures. or heterogeneous with different microstructures, and some parts might possess unique type(s) of epicuticular sculpture. Each species was enumerated based on epicuticular ornamentation, stomata type, stomata formation, stomata frequency, stomata ornamentation, stomata size, trichome distribution and trichome type. The micromorphological descriptions of trichomes, and epicuticular ornamentation were described in Tables 2 and 3.

\begin{tabular}{|c|c|}
\hline Type & Morphology Description \\
\hline I & $\begin{array}{l}\text { laevigate and polyhedral-striated outer periclinal wall; furrowed, straight and rounded anticlinal } \\
\text { wall }\end{array}$ \\
\hline II & foveate outer periclinal wall; fibrillary, undulate and sinuate anticlinal wall \\
\hline III & flat outer periclinal wall; furrowed, straight and rounded anticlinal wall \\
\hline IV & laevigate outer and polygonal periclinal wall; furrowed, straight and rounded anticlinal wall \\
\hline $\mathrm{V}$ & $\begin{array}{l}\text { laevigate, elongated and rectangular outer periclinal wall; furrowed, straight and rounded anticlinal } \\
\text { wall }\end{array}$ \\
\hline VI & microfossulate outer periclinal wall; fibrillary and undulate anticlinal wall \\
\hline VII & $\begin{array}{l}\text { laevigate and irregular shape with undulate striae outer periclinal wall; furrowed, straight and } \\
\text { rounded anticlinal wall }\end{array}$ \\
\hline VIII & $\begin{array}{l}\text { laevigate and elongated rectangular with undulate striae outer periclinal wall; furrowed, straight } \\
\text { and rounded anticlinal wall }\end{array}$ \\
\hline IX & $\begin{array}{l}\text { laevigate and elongated rectangular outer periclinal wall; furrowed, straight and rounded anticlinal } \\
\text { wall }\end{array}$ \\
\hline
\end{tabular}




\section{Species Enumeration and Comparative Study under SEM Examination}

a. V. helvola Blume (Figure 2) - Waxes: scattered, warty-granulated, flake-like and cylindric. Epicuticular ornamentation: Type I, II, III, IV, V, VI and IX. Stomata type: Actinocytic and tetracytic. Stomata formation: paraficial, in parallel or random formation, sunken in the epidermal wall. Stomata frequency and distribution: sparsely occurred on anther and column. Stomata ornamentation: tetracytic — guard cells surrounded by four subsidiary cells with two laterals and two polars, each being present on the four sides, two laterals cells lie parallel to guard cells; actinocytic raised above epidermal layer with ledge cells surrounded by a circle of at least five radially elongated subsidiary cells. Guard cells and ledges distinguishable from the neighbouring stomatal apparatus. Stomatal cuticular striation: striated. Stomatal size: tetracytic - L (38.46-125 $\mu \mathrm{m}) \times \mathrm{W}(35.39$ $83.33 \mu \mathrm{m})$; actinocytic — L (40.91-86.36 $\mu \mathrm{m}) \times \mathrm{W}(56.82-90.91 \mu \mathrm{m})$. Trichome distribution: present on column, labellum and spur. Labellum possessed barrel-shaped papillae or nectaries with aperture on its midlobe. Side lobes bear heterogeneous hairs with unbranched and branched glandular trichomes. On the middle abaxial surface, the spur bears homogenous conical papillae. Trichome type: glandular - Type I, II, III, V and VI. Pustular glands: present. Papillae: present.

b. V. dearei Rchb.f. (Figure 3) - Waxes: scattered, warty-granulated, flake-like and cylindric. Epicuticular ornamentation: Type I, II, IV, VIII and IX. Stomata type: Stephanocytic. Stomataformation: paraficial, in parallel or random formation, semi-raised on the epidermal surfaces or sunken in. Stomata frequency and distribution: sparsely occurred on anther and column. Stomata ornamentation: comprise a more or less well-defined rosette of four or more weakly specialised subsidiary cells. Guard cells and ledges distinguishable from the neighbouring stomatal apparatus. Stomatal cuticular striation: striated. Stomatal size: L (54.55$116.67 \mu \mathrm{m}) \times \mathrm{W}(50-138.89 \mu \mathrm{m})$. Trichome distribution: present on column, labellum and spur. Spur had dense aggregation of conical papillae as nectaries at interior side wall and homogenous trichome type at the centre. Trichome type: non-glandular Type VII; glandular - Type I, III and IV. Pustular glands: present. Papillae: present. 


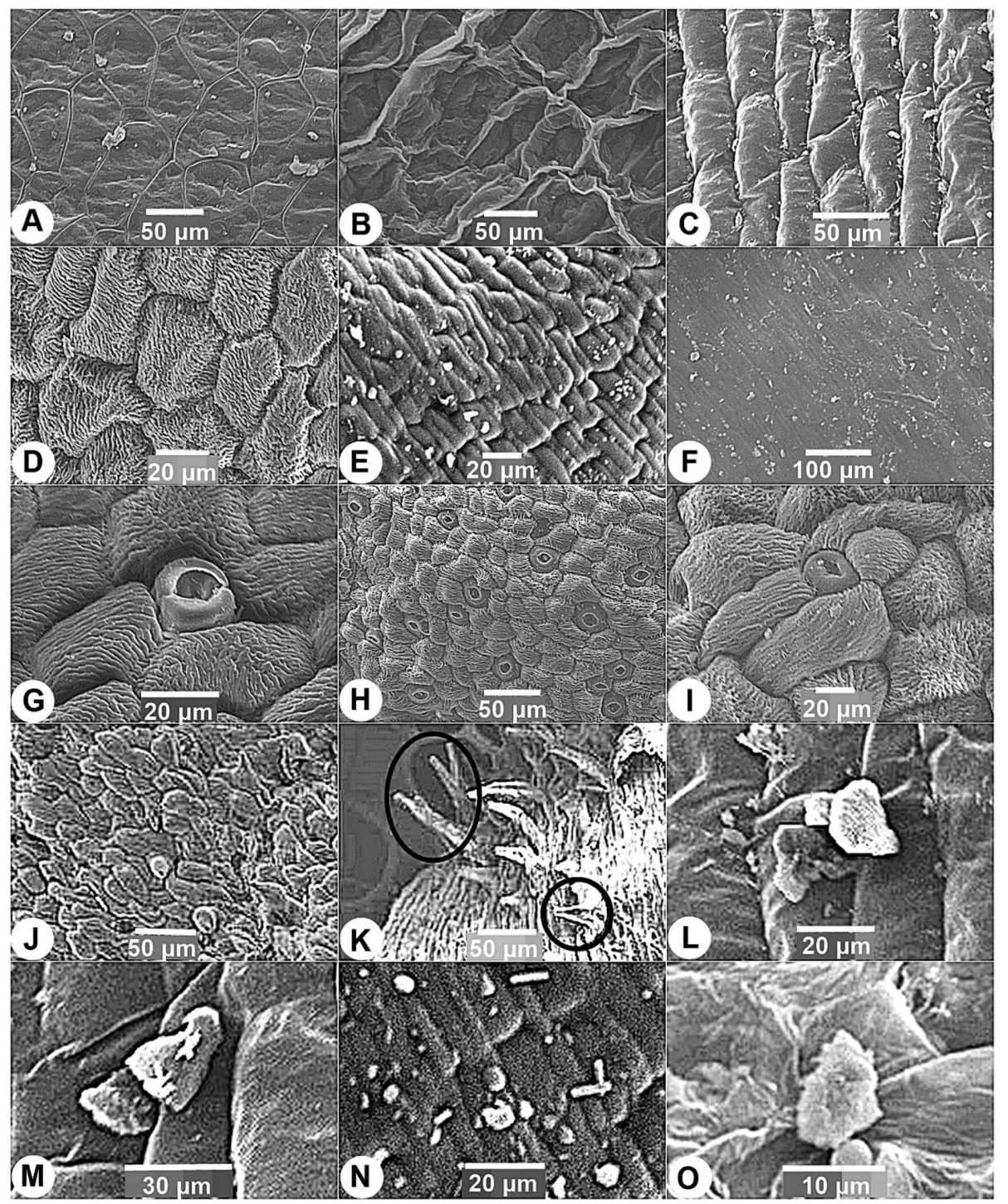

Figure 2: SEM observations of epicuticular ornamentation (A-F), stomata (G-I), trichomes (J\&K) and epicuticular waxes (L-O) on floral parts of $V$. helvola; A: Type III epicuticular ornamentation with flat anticlinal wall; B: Type II foveate epicuticular ornamentation; C: Type V laevigate epicuticular ornamentation; D: Type I epicuticular ornamentation with laevigate and polygehdral-striated anticlinal wall; E: Type IX epicuticular ornamentation with laevigate and elongated rectangular outer periclinal wall; F: Type IX epicuticular ornamentation with unclear periclinal and anticlinal walls; G: Tetracyctic stoma; H: Actinocytic stomata; I: Actinocytic stoma; J: Type II barrel-shaped glandular trichomes with aperture; K: Type V branched and Type VII glandular trichomes (circled); L: Warty-granulated waxes; M: Warty-granulated waxes; N: prismatic crystals intersperse on the surface; and, O: Warty-granulated waxes. 


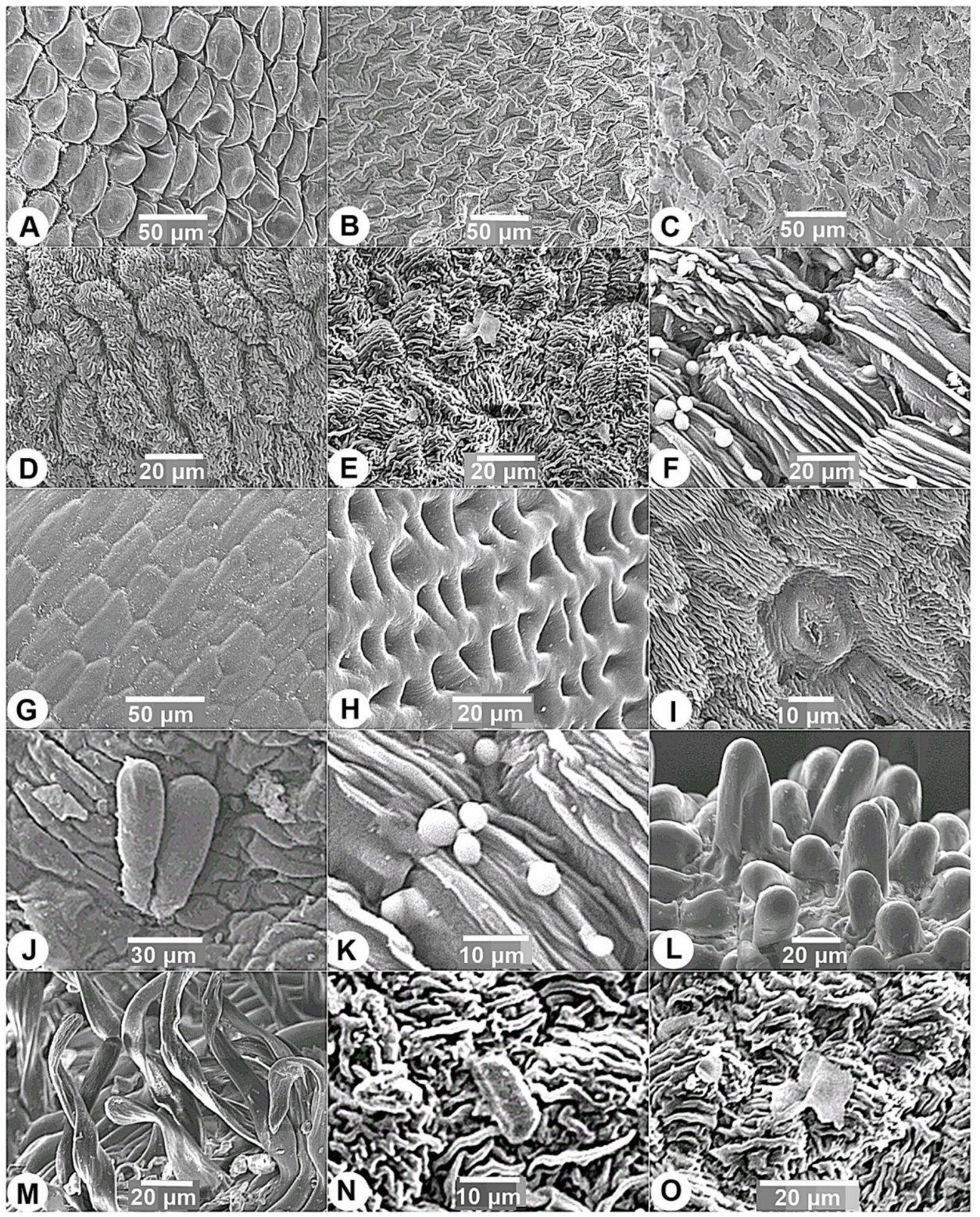

Figure 3: SEM observations of epicuticular ornamentation (A-H), stomata (I), trichomes including papillae (J-M) and epicuticular waxes $(\mathrm{N} \& \mathrm{O})$ on floral parts of $V$. dearei; A: Type IV epicuticular ornamentation with laevigate outer and polygonal periclinal wall; B: Type II epicuticular ornamentation with foveate outer periclinal wall; C: Type II epicuticular ornamentation with foveate outer periclinal wall; D: Type I epicuticular ornamentation with laevigate and polyhedral-striated outer periclinal wall; E: Type VII epicuticular ornamentation with laevigate and irregular shape with undulate striae outer periclinal wall; F: Type I epicuticular ornamentation with laevigate and polyhedral-striated outer periclinal wall; G: Type IX epicuticular ornamentation with laevigate and elongated rectangular outer periclinal wall; H: Type VI epicuticular ornamentation with microfossulate outer periclinal wall; I: Stephanocytic stoma; J: Type IV club-shaped glandular trichomes; K: Barrel-shaped papillae; L: Papillae on spur; M: Type VII non-glandular trichomes on spur; N: Warty-granulated wax; and, O: Flake-like wax. 
Comparative study on the floral-surface micromorphology of $V$. helvola and $V$. dearei

Non-glandular trichomes were observed in both studied species, which varied in structure and distribution on their floral parts, although, glandular trichomes were absent in both species. Stomata were present in floral parts of $V$. helvola and $V$. dearei at a very low frequency and sporadic distribution. Epicuticular ornamentation was prominent and distinctive on the epidermal surface of the selected species, differing in anticlinal and periclinal wall characteristics. The features and occurrence of each micromorphology characteristics are described in Tables 4 and 5.

Table 4: Features and distribution of floral-surface micromorphology characteristics of $V$. helvola and $V$. dearei (trichome)

\begin{tabular}{llllll}
\hline Species & Floral Parts & $\begin{array}{c}\text { Trichome } \\
\text { type }\end{array}$ & $\begin{array}{c}\text { Occurrence of } \\
\text { non-glandular } \\
\text { trichome }\end{array}$ & $\begin{array}{c}\text { Occurrence } \\
\text { of glandular } \\
\text { trichome }\end{array}$ & $\begin{array}{c}\text { Occurrence of } \\
\text { papillae }\end{array}$ \\
\hline V. helvola & Anther & Absent & Absent & Absent & Absent \\
& Column & I & Absent & Low & Low \\
& Dorsal sepal & Absent & Absent & Absent & Absent \\
& Lateral sepals & Absent & Absent & Absent & Absent \\
& Petals & Absent & Absent & Absent & Absent \\
& Labellum & II, V, VI & Absent & High & Absent \\
& Pollinium & Absent & Absent & Low & Absent \\
& Spur & III, VI & Absent & Very high & Very high \\
\hline V. dearei & Anther & Absent & Absent & Absent & Absent \\
& Column & I, IV & Absent & High & Low \\
& Dorsal sepal & Absent & Absent & Absent & Absent \\
& Lateral sepals & Absent & Absent & Absent & Absent \\
& Petals & Absent & Absent & Absent & Absent \\
& Labellum & VII & High & Absent & Absent \\
& Pollinium & Absent & Absent & High & Absent \\
& Spur & III, VII & High & Absent & High \\
\hline
\end{tabular}




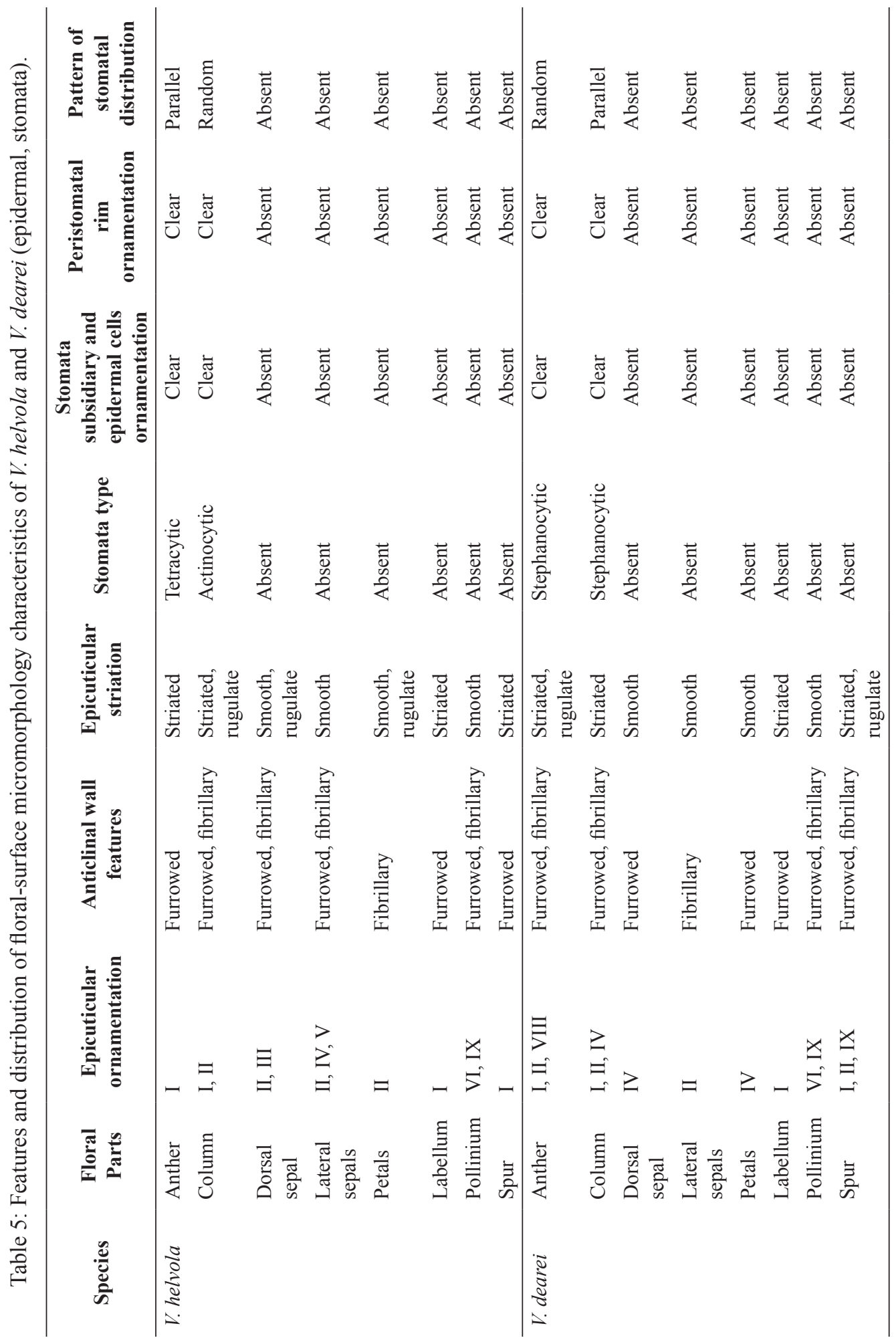




\section{Discussion}

$V$. helvola and $V$. dearei were comparable based on the type and distribution of the epicuticular ornamentation, stomata and trichomes (Tables 4 and 5). Trichomes occurred in the column, labellum and spur of $V$. helvola and $V$. dearei. Glandular trichomes function as the emission layer prescribed by the accumulation of lipid-rich substances, probably precursors or the scent itself (Choi \& Kim, 2013), which explained the scented flowers of both species with glandular trichomes occurring on the labellum and spur. Nectar production also commonly occurred within the spur orchid species, as in Platanthera chlorantha (Custer) Rchb. and Gymnadenia conopsea (L.) R.Br. Nonetheless, other flower parts, such as petals and bracts, could also function as nectaries, as in Platanthera stricta Lindl. and Disa elegans Sond. ex Rchb.f. (Patt et al., 1989; Hobbhahn et al., 2013). Toh et al. (2017) further suggested that both the epidermal layers of the petals and sepals of Vanda Mimi Palmer were preferential sites of scent production and emission.

Presumably, the presence of glandular trichomes and stomata may also offer a food reward to ensure pollinators revisited the plant (Stpiczyñska et al., 2018). Micromorphological studies justified that successful flowerpollinator interactions occurred through the floral micromorphological features, such as nectar secreting trichomes, odour-producing osmophores, or secretory epidermal cells under the cuticle in the labellum and spur (Stpiczyńska, 1993, 2003; Anton et al., 2012). Common types of epidermal conical papillae characterised by its wide base, concave, lateral walls and rounded tip (Davies \& Turner, 2004) found on the column and spur of both studied species might also play a significant role as a secretory structure (Şeker et al., 2016).

Branched glandular trichomes with single secretory cell at the tip occurring on the labellum of $V$. helvola provided morphological significance to differentiate the studied species. Also, stomata diversity offered points on taxonomic delimitation of $V$. helvola and $V$. dearei. $V$. helvola had tetracytic stomata on the anther and actinocytic stomata on the column, whereas $V$. dearei had stephanocytic stomata on the anther and column. Random dispersal of warty-granulated, cylindric and flake-like epicuticular waxes without any unique types on each floral part provided no significance taxonomic value for the studied species as in Corybas (Besi et al., 2019) and Paphiopedilum (unpublished account) species.

Though it might offer protection from desiccation and herbivorous insects (Davies \& Turner, 2004), or reward pollinators with lipids and protein (van der Pijl \& Dodson, 1966; Dressler, 1993; Davies et al., 2003). Contrariwise, the multi-pattern epicuticular ornamentation on the floral parts offered a diagnostic value to discriminate the studied species at species level. Some morphological features shared by both species might indicate relatedness, such as lack of non-glandular trichomes and glabrous epidermal cell of sepals and petals in both species.

\section{Conclusion}

Profiling on floral microstructure and selecting the most suitable media formulation for micropropagation would ensure sustainable use of these two favourite horticulture species. Given the great similarity and hybridisation potential between Vanda species, the comparative investigations of the structure of the trichomes, stomata and epicuticular ornamentation in $V$. helvola and $V$. dearei could provide better understanding of the phylogenetic and taxonomy of the genus. Labellum and spur with glandular trichomes and stomata functioned as the emission sites for either nectar and scent production in $V$. helvola and V.dearei. Further understanding on the usefulness the waxy compound produced by $V$. helvola and $V$. dearei flowers in relation to pollination mechanism would require an investigation into the chemical compounds. 


\section{Acknowledgements}

We like to thank the Forestry Department for granting the permit to access the studied areas. This work was sponsored by the UPMKRIBB (Korea Research Institute of Bioscience and Biotechnology) grant (Vot. 6384300), UPM-Putra Grant (No. 9413603), Young Academic Scheme issued by Universiti Putra Malaysia and IPTA Academic Training Scheme under the Ministry of Higher Education. We appreciate all the people who contributed to the accomplishment of this study, particularly Lam Shun Jia, Cheong Fui Ying, Lai Yian Ee, Tan Yan Bei, Ting Siew Yang, Ng Yong Jin, Tan Mui Ching, Dr. Kenny Khor, Dr. Farah Alia Nordin (plant Taxonomist, Universiti Sains Malaysia), Madam Nur Qamarina Salman and Mr Arif.

\section{References}

Adedeji, O., Ajuwon, O. Y., \& Babawale, O. O. (2007). Foliar epidermal studies, organographic distribution and taxonomic importance of trichomes in the family Solanaceae. International Journal of Botany, 3(3), 276-282.

Angulo, M. B., \& Dematteis, M. (2014). Floral microcharacters in Lessingianthus (Vernonieae, Asteraceae) and their taxonomic implications. Plant Systematics and Evolution, 300(8), 1925-1940.

Anton, S., Kaminska, M., \& Stpiczynska, M. (2012). Comparative structure of the osmophores in the flower of Stanhopea graveolens Lindley and Cycnoches chlorochilon Klotzsch (Orchidaceae). Acta Agrobotanica, 65, 11-22.

Besi, E. E., Lai, Y. E., Khor, H. E., Tan, M. C., Nulit, R., \& Go, R. (2019). FloralSurface Micromorphology of Corybas selangorensis J.Dransf. \& G.Sm. and Corybas holttumii J.Dransf. \& G.Sm. (Orchidaceae). The Journal of the Orchid Society of India, 33, 55-64.

Bridson, D., \& Forman, L. (2000). The herbarium handbook, 3rd edition. Royal Botanic Gardens, Kew. 348 p.
Carpenter, K. J. (2005). Stomatal architecture and evolution in basal angiosperms. American Journal of Botany, 92(10), 15951615.

Chan, C. L., Lamb, A., Shim, P. S., \& Wood, J. J. (1994). Orchids of Borneo, Vol. 1: Introduction and a selection of species. The Sabah Society, Kota Kinabalu \& The Royal Botanic Gardens, Kew. 402 p.

Choi, J. S., \& Kim, E. S. (2013). Structural features of glandular and non-glandular trichomes in three species of Mentha. Applied Microscopy, 43(2), 47-53.

Christenson, E. A. (1987). An infrageneric classification of Holcoglossum Schltr. with a key to the genera of the Aerides-Vanda alliance. Notes from the Royal Botanic Garden, Edinburgh, 44, 249-256.

Davies, K. L., \& Turner, M. P. (2004). Morphology of floral papillae in Maxillaria Ruiz \& Pav. (Orchidaceae). Annals of Botany, 93, 75-86.

Davies, K. L., Turner, M. P., \& Gregg, A. (2003). Lipoidal labellar secretions in Maxillaria Ruiz \& Pav. (Orchidaceae). Annals of Botany, 91, 439-446.

Dressler, R. L. (1993). Phylogeny and classification of the orchid family. Cambridge University Press, Massachusetts. $314 \mathrm{p}$.

Gardiner, L. M. (2012). New combinations in the genus Vanda (Orchidaceae). Phytotaxa, 61(1), 47-54.

Gardiner, L. M., \& Cribb, P. C. (2013). Vanda Renziana. Journal of the Swiss Orchid Foundation, Vol. 3, Swiss Orchid Foundation, Basel.

Gardiner, L. M., Kocyan, A., Motes, M., Roberts, D. L., \& Emerson, B. C. (2013). Molecular phylogenetics of Vanda and related genera (Orchidaceae). Botanical Journal of the Linnean Society, 173(4), 549-572.

Ghazalli, M. N., Tamizi, A. A., Esa, M. I. M., Besi, E. E., Nikong, D., Nordin, A. R. M., 
\& Zaini, A. Z. (2019). The Systematic Significance of Leaf Epidermal MicroMorphology of Ten Nepenthes Species (Nepenthaceae) From Peninsular Malaysia. Reinwardtia, 18(2), 81-96.

Ghimire, B., Jeong, M. J., Suh, G. U., Heo, K., \& Lee, C. H. (2018). Seed morphology and seed coat anatomy of Fraxinus, Ligustrum and Syringa (Oleeae: Oleaceae) and its systematic implications. Nordic Journal of Botany, 36(10), e01866.

Govaerts, R., Bernet, P., Kratochvil, K., Gerlach, G., Carr, G., Alrich, P., Pridgeon, A. M., Pfahl, J., Campacci, M. A., Baptista, D. H., Tigges, H., Shaw, J., Cribb, P., George, A., Kreuz, K., \& Wood, J. J. (2020). World Checklist of Orchidaceae. The Board of Trustees of the Royal Botanic Gardens, Kew. Available from http://apps.kew.org/ wcsp/ (accessed on May 2020)

Hobbhahn, N., Johnson, S. D., Bytebier, B., Yeung, E. C., \& Harder, L. D. (2013). The evolution of floral nectaries in Disa (Orchidaceae: Disinae): recapitulation or diversifying innovation? Annals of botany, 112(7), 1303-1319.

Hodgson, M., Paine, R., \& Anderson, N. (1991). Letts guide to orchids of the world. Charles Letts, London. 219 p.

Kong, M. J., \& Hong, S. P. (2018). The taxonomic consideration of floral morphology in the Persicaria sect. Cephalophilon (Polygonaceae). Korean Journal of Plant Taxonomy, 48(3), 185-194.

Lim, S. H., Chye, P. T., Lee, P. Y. H., \& Goh, C. J. (1999). RAPD analysis of some species in the genus Vanda (Orchidaceae). Annals of Botany, 83, 193-196.

Loh, C. S., Goh, C. J., \& Rao, A. N. (1978). Some factors affecting morphogenesis of Aranda orchid tissue culture. Proceeding of The Symposium on Orchidology. Singapore. pp. 43-55.

Patt, J. M., Merchant, M. W., Williams, E. R., \& Meeuse, B. J. (1989). Pollination biology of Platanthera stricta (Orchidaceae) in Olympic National Park, Washington. American Journal of Botany, 76(8), 10971106.

van der Pijl, L., \& Dodson, C. H. (1966). Orchid flowers, their pollination and evolution. University of Miami Press, Coral Gables, Florida. 214 p.

Piwowarczyk, R. (2015). Seed micromorphology of central European Orobanche and Phelipanche (Orobanchaceae) in relation to preferred hosts and systematic implications. Australian Systematic Botany, 28(3), 124136.

Pridgeon, A. M. (1999). Genera ocrhidacearum. Oxford University Press, Oxford. pp. 67-80.

Savvides, A., Fanourakis, D., \& van Ieperen, W. (2011). Co-ordination of hydraulic and stomatal conductances across light qualities in cucumber leaves. Journal of Experimental Botany, 63(3), 1135-1143.

Seidenfaden, G., \& Wood, J. J. (1992). The Orchids of Peninsula Malaysia and Singapore. Olsen \& Olsen, Fredensborg. $779 \mathrm{p}$.

Şeker, Ş. S., Akbulut, M. K., \& Şenel, G. (2016). Labellum micromorphology of some orchid genera (Orchidaceae) distributed in the Black Sea region in Turkey. Turkish Journal of Botany, 40(6), 623-636.

Shope, J. C., \& Mott, K. A. (2006). Membrane trafficking and osmotically induced volume changes in guard cells. Journal of Experimental Botany, 57, 4123-4131.

Stpiczyńska, M. (1993). Anatomy and ultrastructure of osmophores of Cymbidium tracyanum Rolfe (Orchidaceae). Acta Societatis Botanicorum Poloniae, 62(1-2), 5-9.

Stpiczyńska, M. (2003). Nectar resorption in the spur of Platanthera chlorantha Custer (Rchb.) Orchidaceae-structural and microautoradiographic study. Plant Systematics and Evolution, 238(1-4), 119126. 
Stpiczyńska, M., Płachno, B. J., \& Davies, K. L. (2018). Nectar and oleiferous trichomes as floral attractants in Bulbophyllum saltatorium Lindl. (Orchidaceae). Protoplasma, 255(2), 565-574.

Teoh, E. S. (1980). Asian Orchids. Times Books International, Singapore. 287 p.

Toh, C., Mohd-Hairul, A. R., Ain, N. M., Namasivayam, P., Go, R., Abdullah, N. A. P., Abdullah, M. O., \& Abdullah, J.
O. (2017). Floral micromorphology and transcriptome analyses of a fragrant Vandaceous Orchid, Vanda Mimi Palmer, for its fragrance production sites. $B M C$ research notes, 10(1), 554.

Wilkinson, H. P. (1979). The plant surface (mainly leaf). In: Metacalfe, C.R., \& Chalk, L. Anatomy of dicotyledons, 2nd Edition, Vol. 1 (294 p). Clarendon Press, Oxford. 